\title{
EFFECT OF BIOFERTILIZERS ON THE MORPHOLOGICAL CHARACTERISTICS OF THE BURDOCK
}

\author{
WU, J. ${ }^{1}$ - RADNEZHAD, H. ${ }^{2 *}$ - LONI, A. ${ }^{3}$ - HASSANVAND, A. ${ }^{3}$ - ABARI, M. F. ${ }^{4}$-ZAREMANESH, $\mathrm{H}^{5}$ \\ ${ }^{\text {I} B e i j i n g ~ N o r m a l ~ U n i v e r s i t y, ~ Z h u h a i ~ 519000, ~ C h i n a ~}$ \\ ${ }^{2}$ Department of Biology, Stephen F Austin State University, USA \\ ${ }^{3}$ Department of Biology, Payame Noor University, PO Box 19395-3697, Tehran, Iran \\ ${ }^{4}$ Department of Environmental Science, Stephen F Austin State University, USA \\ ${ }^{5}$ Department of Agriculture, Payame Noor University, PO Box 19395-3697, Tehran, Iran \\ *Corresponding author \\ e-mail: hradnezhad@yahoo.com \\ (Received $11^{\text {th }}$ Oct 2015; accepted $10^{\text {th }}$ Feb 2016)
}

\begin{abstract}
Using eleven treatments, the present study aimed at investigating the influence that organic and inorganic fertilizers exert upon the germination percentage, the length and weight (i.e. dry and fresh) of the shoot and root, and number of leaves which are considered the morphological characteristics associated prominently with the burdock that is technically entitled Arctium lappa. Significant differences were observed between such treatments as urea, vermicompost, vermicompost combined with Nitroxin, $15 \%$ manure in comparison with the control treatment in terms of the germination percentage. Another salient feature of urea and vermicompost treatments was that they led to a decrease in the rate of germination. Vermicompost treatments were proven to be significantly different in terms of number of the plant leaves. Shoot and root length was shown to be significantly influenced by the vermicompost treatments utilized both individually and in combination with Nitroxin. Compared with the control treatment, the experimental treatments were more significant as far as the weight of the fresh root and shoot was concerned. Another source of significant difference in terms of dry root weight was identified to be correlated with the $15 \%$ and $30 \%$ vermicompost individually used as well as the $15 \%$ vermicompost and manure employed in combination with Nitroxin. As for the dry shoot weight, no significant difference was witnessed between Nitroxin and 30\% manure treatments.
\end{abstract}

Keywords: Arctium lappa, growth parameters, inorganic fertilizer, Nitroxin, vermicompost

\section{Introduction}

Arctium lappa Linne, popularly known as burdock or bardana, is a member of the Asteraceae (Compositae) family and can be found worldwide (da Silva et al., 2013). This genus is native to Eurasia (Duistermaat, 1997). In Flora Iranica, three studied species are reported in Gilan, Golestan, Mazandaran, Tehran, Khorasan, Kerman, Lorestan and Azerbaijan provinces (Henry, 2002; Karimi et al., 2001). The morphological characteristics of this plant include the straight and branched stems covered with fluff, heart-shaped leaves, and same-genus heaps and the cluster inflorescences or pistil and almost spherical involucres, bracteoles in several bayonet and narrow rows, akene with cut and slightly compressed tip (Ghahreman, 1994). In addition, the root of burdock is long and fleshy, gray-brown outside and whitish inside, with a somewhat thick bark and soft wood tissue with a radiate structure. It has a sweet taste and crisp texture. Burdock (Arctium lappa L.) has long been cultivated and commonly consumed as a very popular vegetable in Asia (Imahori et al., 2010). The 
nutrients contained in A. lappa include inulin, polyphenols, chlorogenic acid, proteins, carbohydrates, vitamins, amino acids, minerals, and unsaturated fatty acids (Chang et al., 2009). Moreover, in folk medicine, A. lappa had been used to treat throat pain, arthritis, rashes, and various skin problems, and also as a diuretic, depurative, and digestive stimulant (Chan et al., 2011). The burdock beneficial effects observed are related to hypertension, gout, arteriosclerosis, hepatitis and other inflammatory disorders (Lieber, 1994; Tamayo, 2000). The several investigators have been demonstrated that A. lappa displayed hepatoprotective (Lin et al., 2002); antibacterial properties against gram-positive and gram-negative bacteria (Gentil et al., 2006; Pereira et al., 2005) and anti-inflammatory effects (Zhao et al., 2009), which might be due to its free radicalscavenging activity (Leonard et al., 2006). Many of the biological properties attributed to burdock, including antimutagenicity, anticarcinogenicity, and antiaging, may originate from the antioxidant ability of its component (Mclarty, 1997; Niki et al., 1997; Yang et al., 2001).

Roots from A. lappa are popular in the Asian cuisine being widely consumed, whereas the leaves are used as infusions or, externally, as a poultice (Jeelani and Khuroo, 2012). Although the leaves are rich in phenolic compounds (Lou et al., 2010), to which many health benefits are associated (Tamayo et al., 2000; Sun et al., 2011; da Silva et al., 2013), there is a prevalence of investigations on the roots and seeds. Extracts from roots containing several monocaffeoylquinic acids (MCQA) and dicaffeoylquinic acids (DCQA), including several isomers, were reported to have gastroprotective activity (da Silva et al., 2013; Santos et al., 2008). Other compounds were also found in A. lappa, including arctiin and arctigenin, caffeicacid, chlorogenicacid, cynarin, rutin, quercitrin, quercetin, luteolin, benzoic and pcoumaricacid (Lou et al., 2010; Liu et al., 2005). They are associated to the medicinal properties of A. lappa, such as the lignin arctigenin that exhibited antitumor and antidiabetic activities (Awale et al., 2006), these squilignans isolappaol C, lappaol $(\mathrm{C}, \mathrm{D}, \mathrm{F})$ and diarctigenin, which have anti-inflammatory activity (Park et al., 2007). Therefore, improving the productivity and quality of $A$. lappa is an ultimate goal.

Biofertilizers are the formulation of living microorganisms which are able to make atmospheric nitrogen available for the plants (Subba Rao, 1993) and which contain microorganisms capable of transforming the nutritive elements from a non-usable form to a usable one through biological processes (Tien et al., 1979). Several bacteria that are associated with the roots of the crop plants can induce beneficial effects on their hosts and often are collectively referred to as PGPR standing for plant growth promoting rhizobacteria (Azarpour et al., 2011). Nitroxin is a biologic nitrogen fertilizer that contains Azotobacter and Azospirillum (Arun, 2007). Azotobacter and Azospirillum are the two most important non-symbiotic nitrogen-fixing bacteria in non-leguminous crops. Under appropriate conditions, Azotobacter and Azospirillum can enhance plant development and promote the yield of several agriculturally important crops in different soils (Okon and Labendera-Gonzalez, 1994). These beneficial effects of Azotobacter and Azospirillum on plants are attributed mainly to an improvement in root development, an increase in the rate of water and mineral uptake achieved by roots, a displacement of fungi and plant pathogenic bacteria and, to a lesser extent, biological nitrogen fixation (Okon and Itzigshohn, 1995). Furthermore, vermicompost is a product of biodegradation and stabilization of organic materials made by an interaction between earthworms and microorganisms. It contains microbial activities (Edwards, 1998). Vermicompost contains plant-growth regulating materials such as humic acids (Senesi 
et al., 1992; Masciandaro et al., 1997; Atiyeh et al., 2002) and plant growth regulators like auxins, gibberellins, and cytokinins (Krishnamoorthy and Vajrabhiah, 1986; Grappelli et al., 1987; Tomati et al., 1988), which are responsible for the increased plant growth and yield of many crops (Atiyeh et al., 2002).

Therefore, in reference to the mentioned issues, the growth characteristics including the percentage and rate of germination, the number of leaves, roots and shoot height, root and shoot fresh and dry weight of the burdock constituted the focal points of the current study. The effects of Nitroxin (mixed with Azospirillium and Azotobacter), vermicompost and cow manure bio-fertilizers; chemical fertilizers (i.e. urea) at two levels (15 and 30\%) on the morphological characteristics were also examined.

\section{Methods}

\section{Context and Materials of the Study}

The design of the current study was completely randomized, and it was based on some experiments conducted throughout the study using 11 treatments and 4 replications in a greenhouse located in Isfahan (Khorasgan Branch), Islamic Azad University, Isfahan in Iran in 2013-2014. To achieve the main goal of the study, such fertilizers as vermicompost, Nitroxin (Azotobacter and Azospirillium brasilense), cow manure and urea as a chemical fertilizer were utilized along with some pots $\left(16^{*} 19 \mathrm{~cm}\right)$ containing approximately $2 \mathrm{~kg}$ of soil and sand extracted from some farms near the university context mentioned above. The burdock is a biennial (lives 2 years), the most development of leaves and root occurs in second year. However, measurement of vegetative growth of seeds can be determining the deferent fertilizer treatments potential in first year in regard with the potted planting of burdock. In the bottom of pots the holes with a diameter of $1.5 \mathrm{~cm}$ is considered, it is to measure the roots that grow larger than the size of the pot. Moreover the pots embedded in an $80 \mathrm{~cm}$ height of ground surface (Fig. 1).

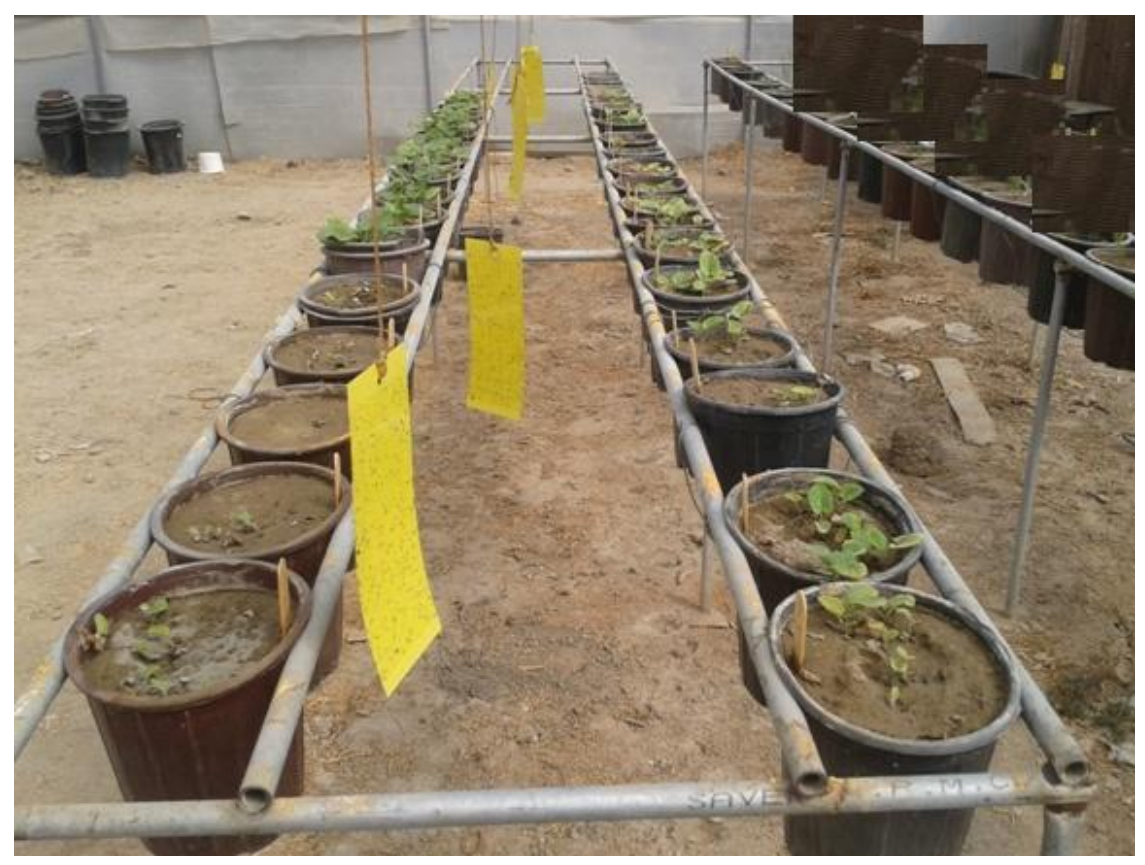

Figure 1. Arrangement of pots in the greenhouses 


\section{Treatments}

The pots 1-4, 5-8, 9-12, 13-16, 17-20, 21-24, 25-28, 29-32, 33-36, 37-40, and 41-44 were comprised of some soil and sand as the control sample of the study (i.e. $15 \%$ vermicompost and $85 \%$ soil, $15 \%$ vermicompost and Nitroxin and $85 \%$ soil, $30 \%$ vermicompost and $70 \%$ soil, $30 \%$ vermicompost and Nitroxin and $70 \%$ soil, Nitroxin and soil, $15 \%$ cow manure and $85 \%$ soil, $15 \%$ cow manure and Nitroxin and $75 \%$ soil, $30 \%$ cow manure and $70 \%$ soil, $30 \%$ cow manure and Nitroxin and $70 \%$ soil, urea and soil, respectively). After 25 burdock seeds were planted in each pot, and the seeds were covered with one centimeter soil, the pots were once irrigated every two days.

\section{Measurement}

The seedlings were counted once a week. On the fourth day, the germinated seeds were counted for 32 days. Finally, after 110 days, the shoot and root length was measured using a transparent ruler, and the normal seedlings were counted again. The leaves of each plant were counted as well. Afterwards, the roots and stems were washed, and the fresh weight was determined. To determine the root and shoot dry weight, the samples were dried in an oven for 48 hours at $72{ }^{\circ} \mathrm{C}$. The dry weight was determined using a digital scale (accuracy level=one ten thousandth of a gram). The germination percentage was calculated using equation (1) below:

$$
\mathrm{PG}=\frac{\mathrm{Ni}}{\mathrm{N}} \times 100
$$

Where PG is the germination percentage, $\mathrm{Ni}$ indicates the number of the germinated seeds per $\mathrm{N}$ day, and $\mathrm{N}$ shows the number of seeds planted.

\section{Statistical Analysis}

All the experiments were repeated four times. The measured data (Tables of the Appendix 1) were analyzed using the analysis of variance (ANOVA), and the mean values of the treatments were compared using Duncan's Multiple Range Test (DMRT) at $\mathrm{P} \leq 0.05$. The 19 th version of the SPSS was used to analyze the whole data.

\section{Results and Discussion}

The results gained from the ANOVA for the vegetative characteristics such as the number of leaves, root and shoot length, fresh and dry weight of root and stem and the germination percentage are shown in Table 1 below.

Table 1. Effect of the treatments on the vegetative characteristics of the medicinal burdock plant

\begin{tabular}{ccccccccc}
\hline Treatment & \% Germination & $\begin{array}{c}\text { Number } \\
\text { of leaves }\end{array}$ & $\begin{array}{c}\text { Root } \\
\text { length } \\
(\mathbf{c m})\end{array}$ & $\begin{array}{c}\text { Stem } \\
\text { length } \\
\text { (cm) }\end{array}$ & $\begin{array}{c}\text { Root } \\
\text { fresh } \\
\text { weight } \\
\text { (gr) }\end{array}$ & $\begin{array}{c}\text { Shoot } \\
\text { fresh } \\
\text { weight } \\
\text { (gr) }\end{array}$ & $\begin{array}{c}\text { Root } \\
\text { dry } \\
\text { weight } \\
\text { (gr) }\end{array}$ & $\begin{array}{c}\text { Shoot } \\
\text { dry } \\
\text { weight } \\
\text { (gr) }\end{array}$ \\
\hline Control & $38 \mathrm{a}$ & $2.75 \mathrm{c}$ & $12.7 \mathrm{a}$ & $1.5 \mathrm{ef}$ & $0.08 \mathrm{f}$ & $0.09 \mathrm{~d}$ & $0.04 \mathrm{f}$ & $0.03 \mathrm{e}$ \\
$\mathbf{\% 1 5}$ Vermi & $39 \mathrm{bcd}$ & $4 \mathrm{ab}$ & $28 \mathrm{bc}$ & $2.87 \mathrm{bcd}$ & $1.25 \mathrm{bc}$ & $0.52 \mathrm{bc}$ & $0.75 \mathrm{bc}$ & $0.23 \mathrm{bcd}$ \\
\hline
\end{tabular}




\begin{tabular}{lcccccccc}
\hline $\begin{array}{c}\text { \%15 Vermi. } \\
\text { Nitroxin }\end{array}$ & $35 \mathrm{~cd}$ & $3.25 \mathrm{bc}$ & $17.75 \mathrm{~b}$ & $3.6 \mathrm{ab}$ & $1.4 \mathrm{~b}$ & $0.82 \mathrm{c}$ & $0.78 \mathrm{ba}$ & $0.30 \mathrm{~b}$ \\
$\begin{array}{c}\text { \%30 Vermi. } \\
\text { \%30 Vermi }\end{array}$ & $37 \mathrm{bcd}$ & $4.5 \mathrm{a}$ & $16.1 \mathrm{~b}$ & $4.25 \mathrm{a}$ & $2.2 \mathrm{a}$ & $1.3 \mathrm{a}$ & $1.1 \mathrm{bcd}$ & $0.56 \mathrm{a}$ \\
$\begin{array}{l}\text { Nitroxin } \\
\text { Nitroxin }\end{array}$ & $16 \mathrm{e}$ & $3.5 \mathrm{abc}$ & $15.75 \mathrm{bc}$ & $3.37 \mathrm{abc}$ & $0.89 \mathrm{bcd}$ & $0.78 \mathrm{~b}$ & $0.5 \mathrm{f}$ & $0.25 \mathrm{bc}$ \\
\%15FYM & $24 \mathrm{de}$ & $3 \mathrm{bc}$ & $10.1 \mathrm{c}$ & $0.75 \mathrm{f}$ & $0.07 \mathrm{f}$ & $0.07 \mathrm{~d}$ & $0.03 \mathrm{def}$ & $0.02 \mathrm{e}$ \\
$\begin{array}{l}\text { \%15 FYM } \\
\text { Nitroxin }\end{array}$ & $39 \mathrm{bcd}$ & $2.5 \mathrm{c}$ & $17.4 \mathrm{~b}$ & $2.1 \mathrm{de}$ & $0.61 \mathrm{def}$ & $0.29 \mathrm{~cd}$ & $0.26 \mathrm{def}$ & $0.12 \mathrm{cde}$ \\
$\begin{array}{l}\text { \%30 FYM } \\
\text { \%30 FYM }\end{array}$ & $53 \mathrm{ab}$ & $3.5 \mathrm{abc}$ & $17.25 \mathrm{~b}$ & $2.8 \mathrm{bcd}$ & $0.8 \mathrm{cde}$ & $0.47 \mathrm{bcd}$ & $0.43 \mathrm{cde}$ & $0.2 \mathrm{bcd}$ \\
Nitroxin & $48 \mathrm{ab}$ & $2.5 \mathrm{c}$ & $17.75 \mathrm{~b}$ & $2.25 \mathrm{cde}$ & $0.20 \mathrm{ef}$ & $0.32 \mathrm{~cd}$ & $0.10 \mathrm{ef}$ & $0.11 \mathrm{de}$ \\
Urea & $60 \mathrm{a}$ & $2.75 \mathrm{c}$ & $16.87 \mathrm{~b}$ & $2.87 \mathrm{bcd}$ & $0.3 \mathrm{def}$ & $0.26 \mathrm{~cd}$ & $0.12 \mathrm{ef}$ & $0.13 \mathrm{cde}$ \\
\hline
\end{tabular}

Means within the column with the same letter are not significantly different by Duncan multiple range test at $\leq 0.05$.

\section{Germination Percentage}

According to the statistical analysis of the experimental data gained from the studied treatments shown in Table 1 above, urea made the most significant difference among all the treatments tends by inhibiting the germination process. Urea has many advantages and is widely used as a nitrogen fertilizer throughout the world of agriculture; however, there are problems related to its use (Engelstad and Hauck, 1974). Some of these problems have adverse effects on germination, seed and early plant growth in soil (Gasser, 1964; Goyal and Huffaker, 1984). The adverse effect of urea on germination is due to the presence of impurities such as biuret (Wilkinson and Ohlrogge, 1960), due to cyanate formed by the isomerization of urea in aqueous solution, $\mathrm{PH}$ or high concentrations of ammonium ions due to hydrolysis of urea by soil urease (Widdowson et al., 1960; Court et al., 1964), Ammonia production from urea hydrolysis (Court et al., 1964), or nitrite production by nitrification and urea nitrogen by soil microorganisms (Court et al., 1964). Bremner and Krogmeier (1989) reported that the effect of urea fertilizer on seed germination of wheat, rye, barley and maize showed that the adverse effects of urea on seed germination in soil is due to ammonia formed by urease hydrolysis which is not related to urea. Impurities in urea as biuret or nitrite resulted from the nitrification of urea nitrogen. The studies compared the effects of germination on soils made by pure urea, urea and impure urea. Also, the compounds formed as a result of changes in soil microbial and enzymatic urea showed that ammonia volatilization from soils treated with urea completely inhibit the germination process.

Both the vermicompost and the vermicompost combined with Nitroxin showed significant differences in comparison with the control treatment. Also, the two treatments $30 \%$ vermicompost combined with Nitroxin and Nitroxin indicated significant differences, but the germination was less than half in the combined treatment. Other treatments including the vermicompost treated both individually and in combination with Nitroxin were not observed to be significantly different from the control treatment. The $15 \%$ vermicompost treatment did not reduce the germination level. Once combined, the $15 \%$ vermicompost treatment turned out to exert a greater effect on the germination process. It is so likely that in the early stages the plants are susceptible to the negative effects of the vermicompost. The studies showed that the 
application of the vermicompost inhibits the germination and seedling growth so that when the concentration of the vermicompost increases, the growth decreases linearly (Ievinsh, 2011). Buckerfield et al. (1999) reported that radish seed germination decreases gradually once the concentration of the vermicompost increases, but a tenfold increase is observed in the $100 \%$ vermicompost as compared with its $10 \%$ counterpart.

In the early stages of growth, the plants were susceptible to the negative effects of vermicompost. Moreover, the stability and maturity are essential for successful application (Wang et al., 2004), Stability is related to microbial activity (Lasaridi and Stentiford, 1998). Puberty refers to the degree of decomposition of organic matter during composting and is produced in the absence of pathogens and weed seeds (Wu et al., 2000). Unstable compost leads to the creation of a competition for oxygen uptake between the biomass and the root or seed. The roots and seeds are deprived from oxygen; the $\mathrm{H}_{2} \mathrm{~S}$ and $\mathrm{NO}_{2}$ reduce (Mathur et al., 1993). According to Nadi et al. (2011), the germination of pistachio in vermicompost cow manure treatments, compared with the control treatments, showed a significant increase owing to the growth of fungi and the disease in seeds in pots treated by the premature vermicompost. Bachman and Metzger (2008) stated that vermicompost were used to improve the growth and a lack of increase in the percentage or rate of germination caused by new seeds and the effect of vermicompost. Joshi and Vig (2010) reported that the highest germination percentage at $15 \%$ vermicompost treatments was observed to be up to $86 \%$, and an increase in the concentrations of the 30 and $45 \%$ treatments that were gradually reduced to 60 and $55 \%$ owing to the presence of excessive nitrogen that inhibited the germination.

As Saleem et al. (2007) mentioned, Plant Growth Promoting Bacteria (PGPR) including the enzymes of amino cyclopropane and dideaminase carboxylic acid (ACC) facilitates the growth of the plant indirectly by reducing plant pathogens, but directly by facilitating the absorption of nutrients through production phytohormone such as auxins, cytokines and gibberellins and enzymes reducing the level of ethylene. They added that PGPR totally breaks the ACC ethylene precursor to utyrate and reduces ammonia and ethylene levels in growing plants. Throughout their study, Gallardo et al. (1994) demostrated that although a large amount of ethylene was not required for the germination of pea seeds, a certain amount was necessary. A comparison made between the cow manure and control treatments indicated that the $15 \%$ cow manure was significantly different from the control treatment, though no difference was found between other sorts of the cow manure treatment and the control treatment. However, the combination of the cow manure treatment and Nitroxin was found to be apt for germination in that the highest germination level was observed to be attributed to the $\% 30$ cow manure treatment combined with Nitroxin. Germination increased when the concentrations of the $\% 15$ to $\% 30$ cow manure treatments increased.

It should be mentioned here that the components of the manure treatment can enhance or hinder the germination process. Studies demonstrate that access to a higher level of nitrogen stimulates the germination of some species (Luna and Moreno, 2009). Using different doses of manure with the purpose of influencing the germination process, Carlos et al. (2013) argued for a threshold level above which cow manure could not be influential in the germination process.

\section{Number of Leaves}

In terms of the number of the leaves, no significant difference was found between $30 \%$ vermicompost treatment combined with Nitroxin, the $15 \%$ vermicompost and the 
$15 \%$ manure treatments combined with Nitroxin. As indicated by Table 1, no significant difference was witnessed between the $15 \%$ and $30 \%$ cow manure treatments. Through the application of vermicompost for the growth of strawberries, Singh et al. (2008) showed that the vermicompost highly influenced such growth parameters as the leaf width and dry weight. This effect was due to the availability of plant growth regulation and humic acid, which is produced by increasing the activity of microbes in vermicompost (Arancon et al., 2004). Microbes such as fungi, bacteria, yeasts and actinomycetes that produce hormones like auxin and gibberellin make a significant amount of vermicompost (Brown, 1995; Arancon et al., 2004).

\section{Stem Length}

The results gained from a statistical analysis of the stem length presented in Table 1 indicate a significant difference made by the vermicompost and the composition of vermicompost and Nitroxin. The 30\% vermicompost treatment which turned out to exert the most significant influence on the stem length exhibited no significant difference from the vermicompost composition, though a significant difference was observed as far as the $15 \%$ vermicompost treatment combined with other treatments was concerned. The greatest impact on the stem elongation was found to be related to the $15 \%$ and $30 \%$ vermicomposts combined with Nitroxin and the 30\% vermicompost treatment. The $15 \%$ vermicompost was more effective once combined with Nitroxin. Joshi and Vig (2010) demonstrated that the application of 15\%, 30\% and 45\% vermicompost treatments increased the height of tomato more significantly than their control treatments. Gutiérrez-Miceli et al. (2007) contended that a significant increase in the average stem diameter and plant height was caused by the use of different doses of sheep manure vermicompost. High microbial activities in the vermicompost are due to fungi, bacteria and autonomists (Tomati et al., 1988). Microorganisms such as bacteria, fungi, yeasts, algae and actionists cause the production of plant growth regulators such as auxin, gibberellins, cytokinin and ethylene (Frankenberger and Arshad, 1995) and vermicompost showed a positive effect on the growth of Begonias and Coleus (Tomati et al., 1988).

Nitroxin treatment, as indicated by Table 1 above, was not significantly different from the control treatments, but it significantly reduced the stem length. The average nitrogen rate of soil or nitrogen by nitrogen fixation is not a barrier to nitrogen fixing but its high levels reduce nitrogen fixing (Marschner, 1995).

The cow manure and its combination with Nitroxin were not observed to be significantly different. This composition had a greater impact on the stem length than the individual application of the cow manure treatment. The differences between the 15 $\%$ and $30 \%$ cow manure and control treatments were not significant.

\section{Shoot Fresh Weight}

As for the fresh weight of the shoots, the vermicompost treatments (i.e. the vermicompost itself and its combined form) were shown to be significantly influential. Specifically, the $30 \%$ vermicompost was found to play the most critical role in the weight than other treatments of the study. According to other studies (Peyvast et al., 2008), the greatest impact on the plant growth and yield was demonstrated to be made by low ratios of vermicompost (20 to $40 \%$ ). A reduction in shoot fresh weight was observed in the Nitroxin treatment, but there was no significant difference between this 
treatment and the control one. The cow manure treatments were found not to be significantly different in this respect. They had not been different from the control treatment neither. However; the stem was much more significantly affected by this treatment than the control treatment of the study.

\section{Shoot Dry Weight}

As for the shoot dry weight, a significant difference between the vermicompost itself and its combined form was found. In addition, the $30 \%$ vermicompost was more significantly influential than other treatments. The Nitroxin treatment decreased the shoot dry weight in comparison with the control treatment, yet the difference was not significant. This treatment was significantly different from other treatments, but the difference existing between the $30 \%$ cow manure treatments applied individually and the one utilized in combination with Nitroxin was not significant. The greatest impact on stem dry weight was found to be correlated with the combination of the $15 \%$ cow manure and Nitroxin.

\section{Root Length}

According to Table 1, significant differences between the experimental and control treatments were observed. The root length increased due to the 15 and $30 \%$ vermicompost treatments. The plants respond differently to different doses of vermicompost due to the production of growth enhancing materials in lower doses than higher doses (Arancon et al., 2004). No significant difference was found between the $15 \%$ vermicompost and $15 \%$ vermicompost combined with Nitroxin, as well as between the $30 \%$ vermicompost treated solely and the one combined with Nitroxin. A root length reduction was observed in $15 \%$ and $30 \%$ vermicompost treatments combined with Nitroxin. Nitroxin treatments were demonstrated not to be significantly different from the $15 \%$ and $30 \%$ vermicompost treatments combined with Nitroxin, but the difference was significant between the Nitroxin and other treatments. Also, a significant reduction in the root length occurred due to the experimental treatments in comparison with the control one. Vessey (2003) opined that an increase in gibberellins can increase cell elongation influenced by biological fertilizers. He asserts that rhizosphere bacteria are likely to cause the synthesis and release of auxin as a matter of secondary metabolites in roots.

Cow manure treatments applied individually or in combination with Nitroxin didn't exert a significant influence on the root length in comparison with the control treatments. Verlinden et al. (2010) conducted a study on the effect of biofertilizers on increasing pasture vegetative organs. The availability of food increased the population and colonization of bacteria in the root of the organic fertilizers combined with Azotobacter and Azospirillium (Siddiqui, 2004).

\section{Root Fresh Weight}

As presented by Table 1, the vermicompost treatment applied both individually and in combination with Nitroxin made a significant influence upon the fresh weight of the roots in comparison with the control treatment. The $30 \%$ vermicompost was the most significantly influential in the root fresh weight among all the treatments of the current study. This significance can lie in the increasing amount of available nutrients, the number of beneficial microorganisms, enzyme activities and plant growth promoters 
such as gibberellin, cytokinin and auxin. Kadam and Pathade (2014) showed that using the proper proportions of vermicompost, root fresh weight increased more significantly in the experimental treatment than its control counterpart. In their study, the Nitroxin treatment showed no significant differences, but it led to a higher reduction in the root fresh weight in comparison with the control treatment. The cow manure treatments were greatly but insignificantly effective in the fresh weight as compared with the control treatments.

\section{Root Dry Weight}

Regarding the root dry weight, the vermicompost treatments, especially the $30 \%$ form, had a more significant influence than the control treatment. Bachman and Metzger (2008) examined the effect of $10 \%$ and $20 \%$ vermicompost treatments on marigold, revealing that the latter brought about a greater increase in shoot and root dry weight than the former. In their study, the Nitroxin treatment showed no significant differences as compared to the control treatment. The cow manure treatments, especially the $15 \%$ form, and their combination with Nitroxin were more significant than other treatments in this respect.

\section{Conclusions}

The results gained from the current study showed different effects of application of vermicompost, biological, cow manure and urea fertilizers on the germination process. The germination percentage of the vermicompost and Nitroxin decreased in comparison with the control treatment. The cow manure treatment and its combination with Nitroxin increased the germination percentage. Furthermore, a higher dose of the vermicompost treatment was found to be more influential in the number of the leaves. Both levels of the cow manure treatment turned out to be negatively influencial in the number of the leaves. A negative effect was found to be made by the Nitroxin treatment on the shoot fresh weight. Regarding the shoot dry weight, all the study treatments had a great effect except for Nitroxin. In terms of the root length, all treatments were significantly different in comparison with the control treatment. The $15 \%$ vermicompost applied individually, the $15 \%$ vermicompost used in combination with Nitroxin, and the $30 \%$ cow manure were witnessed to be the most significantly influential, but the Nitroxin was found to have a negative influence. Of all the treatments included in the present research study, the 30\% vermicompost treatment had the highest effect on the root fresh weight which was differently influenced by the experimental treatments (i.e. vermicomposts) and the control treatment. The root dry weight was shown to be positively significantly influenced by the $15 \%$ and $30 \%$ vermicomposts, and the $15 \%$ cow manure treatment combined with Nitroxin. More importantly, the vermicompost treatments applied individually and in combination with Nitroxin had the greatest effect among all the treatments. The $30 \%$ vermicompost was observed to be the highest in this respect. The organic manures and their combination with biofertilizers played a crucial role in the growth of burdock. As for the number of the leaves, stem length, fresh and dry weights of the roots and shoots, the higher doses of the vermicompost $30 \%$ were more influential than the $15 \%$ vermicompost treatment. Regarding the characteristics such as the germination percentage, the number of the leaves, and the length of the roots, the $15 \%$ vermicompost assumed the most significant role, whereas the combined version of the vermicompost treatment was most influential in other parameters. 
The individual and non-individual application of the $15 \%$ vermicompost treatment had a negative effect, so this level was proved to be far from optimal as far as the morphological characteristics were concerned. The negative impact of Nitroxin treatment (containing Azotobacter and Azospirillium) was probably due to the negative interplay between two bacteria. The $15 \%$ cow manure applied both individually and non-individually was significantly influential in all parameters except for the root length, but the $30 \%$ counterpart had the highest impact on all the features of the plant. Consequently, it is suggested that a lower dose of the animal manure be applied in order to enhance the growth of burdock. However, as for the germination percentage, and the shoot and root dry weight, the combined form is highly recommended. A lower dose of other treatments combined with Nitroxin is suggested once other parameters are intended to be taken into consideration.

\section{REFERENCES}

[1] Arancon, N. Q., Edwards, C. A., Bierman, P., Welch, C., Metzer, J. D. (2004): Influence of vermicomposts on field strawberries: effect on growth and yields. - Bioresource Technology 93: 145-153.

[2] Arun, K. S. (2007): Bio-fertilizers for sustainable agriculture. Mechanism of Psolubilization (6th ed.). - Agribios publishers, Jodhpur, India, 196-197 p.

[3] Atiyeh, R. M., Edwards, C. A., Subler, S., Metzger, J. (2002): Earthworm-processed organic waste as components of horticultural potting media for growing marigold and vegetable seedlings. - Compost Science and Utilization 8(3): 215-253.

[4] Awale, S., Lu, J., Kalauni,S. K., Kurshima, Y., Tesuka, Y., Kadota, S., Esumi, H. (2006): Identification of arctigenin as an antitumor agent having the ability to eliminate the tolerance of cancer cells to nutrients starvation. - Cancer Research 66:1751-1757.

[5] Azarpour, E., Tarighi, F., Moradi, M., Bozorgi, H. R. (2011): Evaluation effect of different nitrogen fertilizer rates under irrigation management in rice farming. - World Applied Sciences Journal 13(5): 1248-1252 .

[6] Bachman, G. R., Metzger, J. D. (2008): Growth of bedding plants in commercial potting substrate amended with vermicompost. - Bioresource Technology 99: 3155-3161.

[7] Bremner, J. M., Krogmeier, M. J. (1989): Evidence that the adverse effect of urea fertilizer on seed germination in soil is due to ammonia formed through hydrolysis of urea by soil urease. - Proceedings of the National Acedemy of Sciences of the United States of America 86(21): 8185-8188.

[8] Brown, G. G. (1995): How do earthworms affect micro floral and faunal community diversity? - Plant and Soil 170: 209-231.

[9] Buckerfield, J. C., Flavel, T. C., Lee, K. E., Webster, K. A., Osmaond, G. (1999): Vermicompost in soild and liquid forms as a plant growth promoter. - Pedobiologia 43: 753-759.

[10] Carlos, P. C., Azcárate, M. F., Peco, B. (2013): Does cattle dung cause differences between grazing increaser and decreaser germination response. - Acta Oecologica $47: 1$ 7.

[11] Chan, Y. S., Cheng, L. N., Wu, J. H., Chan E., Kwan, Y. W., Lee, S. M., Leung, G. P., Yu, P. H., Chan, S. W. (2011): A review of the pharmacological effects of Arctium lappa (burdock). - Inflammopharmacology 19(5):245-254.

[12] Chang, H. J., Huang, W. T., Tsao, D. A., Huang, M. K., Lee, C. S., Lin, R. S., Yang, C. S., Yeh, S. C. (2009): Identification and authentication of burdock (Arctium lappa L.) using PCR sequencing. - Fooyin Journal of Health Sciences 1(1): 28-32.

[13] Court, M. N., Stephen, R. C. Waid, J. S. (1964): Toxicity as a cause of the inefficiency of urea as a fertilizer II. experimental. - Journal of Soil Sciences 15(1): 49-67. 
[14] da Silva, L. M., Allemand, A., .Mendes, D. A., Santos, A. C., André, E., de Souza, L. M., Cipriani, T. R., Dartora, N., Marques, M. C., Baggio, C. H., Werner, M. F. (2013): Ethanolic extract of roots from Arctium lappa L. accelerates the healing of acetic acidinduced gastric ulcer in rats: Involvement of the antioxidant system. - Food and Chemical Toxicology 51:179-187.

[15] Duistermaat, H. (1997): Arctium getting entangled to Cousinia (Asteraceae: Cardueae). Bocconea 5(2): 686-689.

[16] Edwards, C. A. (1998) The use of earthworm in the breakdown and management of organic waste. - In: Edwards, C. A. (ed.). Earthworm Ecology. ACA Press LLC, Boca Raton, FL, 327-354.

[17] Engelstad, O. P., Hauck, R. D. (1974): Urea: Will it become the most popular nitrogen carrier? - Crops Soils 26: 11-14.

[18] Frankenberger, Jr. W. T., Arshad, M. (1995): Phytohormones in Soils: Microbial Production and Function. - Marcel and Decker, New York. pp: 503.

[19] Gallardo, M., Munozderueda, P., Matilla, A., Sanchez- Calle, M. (1994): The relationships between ethylene production and germination of Cicer arietinum seeds. Biologia Plantarum 36(2): 201-207.

[20] Gasser, J. K. R. (1964): Urea as a fertilizer. - Soils \& Fertilizers 27: 175-180.

[21] Gentil, M., Pereira, J. V., Sousa, Y. T., Pietro, R., Neto, M. D., Vansan, L. P., de Castro Franca, S. (2006): In vitro evaluation of the antibacterial activity of Arctium lappa as a phytotherapeutic agent used in intracanal dressings. - Phytotherapy Research 20(3): 184186.

[22] Ghahreman, A. (1994): Pant systematics: Cormophytes of Iran. - Iran University Press, Teheran.

[23] Goyal, S. S., Huffaker, R. C. (1984): Nitrogen toxicity in plants. - In: Hauck, D. R. (ed.). Nitrogen in Crop Production. American Society of Agronomy, Crop Science Society of America, Soil Science Society of America, Madison.

[24] Grappelli, D. H., Gallli, E., Tomati, U. (1987): Earthworm casting effect on Agaricus bisporus fructification. - Agrochimica 21: 457-462.

[25] Gutiérrez-Miceli, A. F., Santiago-Borraz, J., Molina, M. A. J., Nafate, C. C., AbudArchila, M., Llaven, O. A. M., Rincón-Rosales, R., Dendooven, L. (2007): Vermicompost as a soil supplement to improve growth, yield and fruit quality of tomato (Lycopersicum esculentum). - Bioresource Technology 98: 2781-2786.

[26] Henry, R. J. (2002): Practical Applications of Plant Molecular Biology. - Chapman \& Hall, London. Translated by: Bagheri, A. R.; Izadi Darbandi A., Malbouni, M. A. Ferdowsi University of Mashhad 56-58.

[27] Ievinsh, G. (2011): Vermicompost treatment differentially affects seed germination, seedling growth and physiological status of vegetable crop species. - Plant Growth Regulation 65(1): 169-181.

[28] Imahori, Y., Kitamura,N., Kobayashi, S., Takihara,T., Ose, K., Ued, Y. (2010): Changes in fructooligosaccaride composition and related enzyme activities of burdock root during low-temperature storage. - Postharvest Biology and Technology 55: 15-20.

[29] Jeelani, S., Khuroo, M. A. (2012) Triterpenoids from Arctium lappa. - Natural Product Research 26: 654-658.

[30] Joshi, R., Vig, A. P. (2010): Effect of Vermicompost on Growth, Yield and Quality of Tomato (Lycopersicum esculentum L.). - African Journal of Basic \& Applied Sciences 2(3-4): 117-123.

[31] Kadam, D., Pathade, G. (2014) Effect of tendu (Diospyros melanoxylon RoxB.) leaf vermicompost on growth and yield of French bean (Phaseolus vulgaris L.). International Journal of Recycling Organic Waste in Agriculture 3: 44

[32] Karimi Shahri, M. R., Dehavari. V., Hajian-Shahri, M., Mokhtarian, A. (2001): Several varieties of grapes in Khorasan Razavi Province based on RAPD and ISSR genetic markers. - Seed and Plant breeding Journal 28(2): 159-172. 
[33] Krishnamoorthy, R. V., Vajrabhiah, S. N. (1986): Biological activity of earthworm casts: an assessment of plant growth promoter levels in casts. - Proceedings of the Indian Academy of Sciences (Animal Science) 95: 341-351.

[34] Lasaridi, K. E., Stentiford, E. I. (1998): A simple respirometric technique for assessing compost stability. - Water Research 32: 3717-3723.

[35] Leonard, S. S., Keil, D., Mehlman, T., Proper, S., Shi, X., Harris, G. K. (2006): Essiac tea: scavenging of reactive oxygen species and effects on DNA damage. - Journal of Ethnopharmacology 103: 288-296.

[36] Lieber, C. S. (1994): Alcohol and the liver. - Gastroenterology 106(4): 1085-1105.

[37] Lin, S. C., Lin, C. H., Lin, C. C., Lin, Y. H., Chen, C. F., Chen, I. C., Wang, L. Y. (2002): Hepatoprotective effects of Arctium lappa Linne on liver injuries induced by chronic ethanol consumption and potentiated by carbon tetrachloride. - Journal of Biomedical Science 9: 401-409.

[38] Liu, S., Chen, K., Schlieman, D. (2005): Isolation and identification of arctiin e arctigenin in leaves of burdock (Arctium lappa L.) by polyamide column chromatography in combination with HPLC-ESI/MS. - Phytochemical Analysis 16: 86-89.

[39] Lou, Z., Wang, H., Zhu, S., Zhang, M., Gao, C., Ma, C., Wang, Z. J. (2010): Improved extraction and identification by ultra performance liquid chromatography tandem mass spectrometry of phenolic compounds in burdock leaves. - Journal of Chromatography A1217: 2441-2446.

[40] Luna, B., Moreno, J. M. (2009) Light and nitrate effects on seed germination of Mediterranean plant species of several functional groups. - Plant Ecology 203(1): 123135.

[41] Marschner, H. (1995): Mineral nutrition of higher plants. - Annals of Botany 78(4):527528.

[42] Masciandaro, G., Ceccanti, B., Gracia, C. (1997): Soil agro-ecological management: fetigation and vermicompost treatments. - Bioresource Technology 59: 199-206.

[43] Mathur, S. P., Owen, G., Dinel, H., Schnitzer, M. (1993): Determination of compost biomaturity. - Biological Agriculture and Horticulture 10: 65-85.

[44] Mclarty, J. W. (1997): Antioxidants and cancer, the epidemologic evidence. - In: Garewal, H. S. (Ed.). Antioxidants and Disease Prevention. CRC Press, New York, pp. 45-66.

[45] Nadi, M., Golchin, A., Mozafari, V., Saeidi, T., Sedaghati, E. (2011): The Effects of Different Vermicomposts on the Growth and Chemical Composition of the Pistachio Seedlings. - Journal of Research in Agricultural Science 7(1): 59-69.

[46] Niki, E. (1997): Free radicals, Antioxidants and Cancer. - In: Ohigashi, H., Osawa, T., Terao, J., Watanabe, S., Yoshikawa, T. (eds.). Food Factors for Cancer Prevention. Springer, Tokyo, pp.55-57.

[47] Okon, Y., Itzisohn, R. (1995): The development of Azospirillum as a commercial inoculant for improving crop yields. - Biotechnology Advances 13: 414-424.

[48] Okon, Y., Labandera-Gonzalez, C. (1994): Agronomic applications of Azospirillum: an evaluation of 20 years worldwide field inoculation. - Soil Biology and Biochemistry 26: 1591-1601.

[49] Park, S. Y., Hong, S. S., Han, X. H., Hwang, J. S., Lee, D., Ro, J. S., Hwang, B. Y. (2007): Lignans from Arctium lappa and their in hibition of LPS-induced nitric oxide production. - Chemical and Pharmaceutical Bulletin 55: 150-152.

[50] Pereira, J. V., Bergamo, D. C., Pereira, J. O., Franca Sde, C., Pietro, R. C., Silva-Sousa, Y. T. (2005): Antimicrobial activity of Arctium lappa constituents against microorganisms commonly found in endodontic infections. - Brazilian Dental Journal 16: 192-196.

[51] Peyvast, G. H., Olfati, J. A., Madeni, S., Forghani, A. (2008): Effect of vermicompost on the growth and yield of spinach (Spinacia oleracea L.). - Journal of Food, Agriculture \& Environment 6(1): $110-113$. 
[52] Santos, A. C., Baggio, C. H., Freitas, C. S., Lepieszynski, J., Mayer, B., Twardowschy, A., Missau, F. C., Santos, E. P., Pizzolatti, M. G., Marques, M. C. A. (2008): Gastroprotective activity of the chloroform extract of the roots from Arctium lappa L. Journal of Pharmacy and Pharmacology 60: 795-801.

[53] Saleem, M., Arshad, M., Hussain, S., Bhatti, A.S. (2007): Perspective of plant growth promoting rhizobacteria (PGPR) containing ACC deaminase in stress agriculture. - J. Ind. Microbiol. Biotechnol. 34: 635-648.

[54] Senesi, N., Saiz-Jimenez, C., Miano, T. M. (1992) Spectroscopic characterization of metal-humic acid-like complexes of earthworm-composted organic wastes. - The Science of the Total Environment (117/118): 111-120.

[55] Siddiqui, Z. A. (2004): Effects of plant growth promoting bacteria and composed organic fertilizers on the reproduction of Meloidogyne incognita and tomato growth. Bioresource Technology 95: 223-227.

[56] Singh, R., Sharma, R. R., Kumar, S., Gupta, R. K., Patil, R. T. (2008): Vermicompost substitution influences growth, physiological disorders. Fruit yield and quality of strawberry (Fragaria ananassa Duch.). - Bioresource Technology 99: 8507-8511.

[57] Subba Rao, S. N. (1993): Biofertilizers in Agriculture and Forestry (3rd ed.). - Oxford \& IBM publishing Company, Delhi, India.

[58] Sun, L., Zhang, J., Lu, X., Zhang, L., Zhang, Y. (2011): Evaluation to the antioxidant activity of total flavonoids extract from persimmon (Diospyros kaki L.) leaves. - Food and Chemical Toxicology 49: 2689-2696.

[59] Tamayo, C., Richardson, A. M., Diamond, S., Skoda, I. (2000): The chemistry and biological activity of herbs used in Flor-Essence ${ }^{\mathrm{TM}}$ herbal tonic and Essiac. Phytotherapy Research 14(1): 1-14.

[60] Tien, T. N., Gaskins, N. H., Hubbell, D. H. (1979): Plant growth substances produced by Azospirillum brasilense and their effect on growth of Pearl Millet. - Applied and Environmental Microbiology 37: 1016-1024.

[61] Tomati, U., Grappelli, A., Galli, E. (1988): The harmone like effect of earthworm casts on plant growth. - Biology and Fertility of Soils 5: 288-294.

[62] Verlinden ,G., Coussens, T., De Vliegher, A., Baert, G., Haesaert, G. (2010): Effect of humic substances on nutrient uptake by herbage and on production and nutritive value of herbage from sown grass pastures. - Grass and Forage Science 65: 133-144.

[63] Vessey, J. K. (2003): Plant growth promoting rhizobacteria as biofertilizer. - Plant and Soil 255: 271-286.

[64] Wang, P., Changa, C. M., Watson, M. E., Dick, W. A., Chen, Y., Hoitink, H. A. J. (2004): Maturity indices for composted dairy and pig manures. - Soil Biology and Biochemistry 36: 767-776.

[65] Widdowson, F. V., Penney, A., Cooke, G. W. (1960): The value of calcium nitrate and urea for main-crop potatoes and kale. - Journal of Agricultural Sciences 55: 1-10.

[66] Wilkinson, S. R. Ohlrogge, A. J. (1960): Influence of biuret and urea fertilizers containing biuret on corn plant growth and development. - Agronomy Journal 52: 560562.

[67] Wu, L., Ma, L. Q., Martinez, G. A. (2000): Comparison of methods for evaluating stability and maturity of biosolids compost. - Journal of Environmental Quality 29: 424429.

[68] Yang, C. S., Landau ,J. M., Huang, M. T., Newmark, H. L. (2001): Inhibition of carciogenesis by dietary polyphenolic compounds. - Annual Review of Nutrients 21: 381-406.

[69] Zhao, F., Wang, L., Liu, K. (2009): In vitro anti-inflammatory effects of arctigenin, a lignan from Arctium lappa L., through inhibition on iNOS pathway. - Journal of Ethnopharmacology 122: 457-462. 


\section{APPENDIX}

Appendix 1. Tables of burdock biometric variation in different treatment

\begin{tabular}{|c|c|c|c|c|c|c|c|c|}
\hline Pot & $\begin{array}{l}\text { Root } \\
\text { height } \\
\text { (cm) }\end{array}$ & $\begin{array}{c}\text { Stem } \\
\text { height } \\
\text { (cm) }\end{array}$ & $\begin{array}{l}\text { Root fresh } \\
\text { weight (gr) }\end{array}$ & $\begin{array}{c}\text { Stem } \\
\text { fresh } \\
\text { weight } \\
\text { (gr) }\end{array}$ & $\begin{array}{c}\text { Dry } \\
\text { root } \\
\text { weight } \\
\text { (gr) }\end{array}$ & $\begin{array}{c}\text { Dry } \\
\text { stem } \\
\text { weight } \\
\text { (gr) }\end{array}$ & $\begin{array}{c}\text { Number } \\
\text { of leave }\end{array}$ & Germination \% \\
\hline 1 & 8 & 1.5 & 0.07 & 0.06 & 0.03 & 0.04 & 4 & 44 \\
\hline 2 & 17 & 1.5 & 0.11 & 0.12 & 0.05 & 0.05 & 3 & 40 \\
\hline 3 & 15.5 & 2 & 0.11 & 0.11 & 0.08 & 0.05 & 2 & 40 \\
\hline 4 & 10.5 & 1 & 0.06 & 0.07 & 0.01 & 0.01 & 2 & 28 \\
\hline 5 & 34 & 3.5 & 1.2 & 0.53 & 0.71 & 0.2 & 4 & 32 \\
\hline 6 & 22 & 3.5 & 1.12 & 0.65 & 0.73 & 0.24 & 4 & 36 \\
\hline 7 & 29 & 2.5 & 1.6 & 0.45 & 0.84 & 0.23 & 4 & 40 \\
\hline 8 & 27 & 2 & 1.11 & 0.48 & 0.73 & 0.27 & 4 & 48 \\
\hline 9 & 17 & 3 & 1.12 & 0.56 & 0.6 & 0.22 & 3 & 32 \\
\hline 10 & 18.5 & 3.5 & 1.45 & 0.76 & 0.74 & 0.25 & 3 & 36 \\
\hline 11 & 17.5 & 4 & 1.85 & 0.82 & 1.1 & 0.31 & 3 & 32 \\
\hline 12 & 18 & 4 & 1.23 & 1.15 & 0.69 & 0.44 & 4 & 40 \\
\hline 13 & 18.5 & 4.5 & 2.12 & 0.95 & 1.15 & 0.42 & 5 & 52 \\
\hline 14 & 15 & 4 & 2.85 & 1.12 & 1.54 & 0.54 & 5 & 36 \\
\hline 15 & 16.5 & 4.5 & 1.46 & 1.4 & 0.71 & 0.49 & 4 & 32 \\
\hline 16 & 14.5 & 4 & 2.46 & 1.9 & 1.39 & 0.79 & 4 & 28 \\
\hline 17 & 15.5 & 3.5 & 2.21 & 1.64 & 1.25 & 0.46 & 3 & 20 \\
\hline 18 & 17.5 & 3.5 & 0.31 & 78.2 & 0.17 & 0.22 & 3 & 16 \\
\hline 19 & 18 & 5 & 0.83 & 0.51 & 0.41 & 0.25 & 5 & 16 \\
\hline 20 & 12 & 1.5 & 0.21 & 0.22 & 0.17 & 0.09 & 3 & 12 \\
\hline 21 & 9.5 & 0.5 & 0.09 & 0.11 & 0.05 & 0.02 & 3 & 40 \\
\hline 22 & 7.5 & 0.5 & 0.02 & 0.03 & 0.01 & 0.01 & 2 & 4 \\
\hline 23 & 9.5 & 1 & 0.08 & 0.09 & 0.03 & 0.05 & 4 & 28 \\
\hline 24 & 14 & 1 & 0.09 & 0.06 & 0.04 & 0.03 & 3 & 24 \\
\hline 25 & 13 & 1.5 & 0.25 & 0.16 & 0.15 & 0.05 & 3 & 60 \\
\hline 26 & 24 & 2.5 & 0.68 & 0.31 & 0.38 & 0.11 & 2 & 52 \\
\hline 27 & 18.5 & 2 & 0.78 & 0.26 & 0.21 & 0.14 & 2 & 20 \\
\hline 28 & 14 & 2.5 & 0.74 & 0.46 & 0.32 & 0.18 & 3 & 24 \\
\hline 29 & 13.5 & 2.5 & 0.74 & 0.35 & 0.43 & 0.16 & 4 & 40 \\
\hline 30 & 13.5 & 3 & 0.72 & 0.36 & 0.39 & 0.15 & 3 & 60 \\
\hline 31 & 17 & 3 & 0.81 & 0.62 & 0.41 & 0.25 & 3 & 60 \\
\hline 32 & 25 & 3 & 0.95 & 0.57 & 0.49 & 0.26 & 4 & 52 \\
\hline 33 & 22 & 3 & 0.36 & 0.54 & 0.21 & 0.19 & 3 & 48 \\
\hline 34 & 20.5 & 2.5 & 0.15 & 0.39 & 0.09 & 0.11 & 3 & 56 \\
\hline 35 & 17.5 & 3 & 0.31 & 0.35 & 0.11 & 0.14 & 3 & 48 \\
\hline 36 & 11 & 0.5 & 0.01 & 0.02 & 0.001 & 0.001 & 1 & 40 \\
\hline 37 & 15.5 & 2 & 0.47 & 0.34 & 0.25 & 0.23 & 2 & 64 \\
\hline 38 & 20 & 2.5 & 0.39 & 0.27 & 0.16 & 0.11 & 3 & 60 \\
\hline 39 & 17 & 3 & 0.31 & 0.21 & 0.06 & 0.05 & 3 & 56 \\
\hline 40 & 15 & 4 & 0.03 & 0.23 & 0.01 & 0.12 & 3 & 60 \\
\hline
\end{tabular}


Appendix 2. The effect of treatment on burdock growth parameters

\begin{tabular}{|c|c|c|c|c|c|c|c|c|}
\hline Pot & $\begin{array}{c}\text { Root } \\
\text { height } \\
(\mathbf{c m})\end{array}$ & $\begin{array}{c}\text { Stem } \\
\text { height } \\
(\mathbf{c m})\end{array}$ & $\begin{array}{c}\text { Root } \\
\text { fresh } \\
\text { weight } \\
\text { (gr) }\end{array}$ & $\begin{array}{c}\text { Stem } \\
\text { fresh } \\
\text { weight } \\
\text { (gr) }\end{array}$ & $\begin{array}{c}\text { Dry } \\
\text { root } \\
\text { weight } \\
\text { (gr) }\end{array}$ & $\begin{array}{c}\text { Dry } \\
\text { stem } \\
\text { weight } \\
\text { (gr) }\end{array}$ & $\begin{array}{c}\text { Number } \\
\text { of leaves }\end{array}$ & Germination\% \\
\hline 1 & 34 & 3.5 & 1.2 & 0.53 & 0.71 & 0.2 & 4 & 32 \\
\hline 2 & 22 & 3.5 & 1.12 & 0.65 & 0.73 & 0.24 & 4 & 36 \\
\hline 3 & 29 & 2.5 & 1.6 & 0.45 & 0.84 & 0.23 & 4 & 40 \\
\hline 4 & 27 & 2 & 1.11 & 0.48 & 0.73 & 0.27 & 4 & 48 \\
\hline 5 & 28 & 2.875 & 1.2575 & 0.5275 & 0.7525 & 0.235 & 4 & 39 \\
\hline 6 & 9.5 & 0.5 & 0.09 & 0.11 & 0.05 & 0.02 & 3 & 40 \\
\hline 7 & 7.5 & 0.5 & 0.02 & 0.03 & 0.01 & 0.01 & 2 & 4 \\
\hline 8 & 9.5 & 1 & 0.08 & 0.09 & 0.03 & 0.05 & 4 & 28 \\
\hline 9 & 14 & 1 & 0.09 & 0.06 & 0.04 & 0.03 & 3 & 24 \\
\hline 10 & 10.125 & 0.75 & 0.07 & 0.0725 & 0.0325 & 0.0275 & 3 & 24 \\
\hline- & - & - & - & - & - & - & - & - \\
\hline 11 & 13 & 1.5 & 0.25 & 0.16 & 0.15 & 0.05 & 3 & 60 \\
\hline 12 & 24 & 2.5 & 0.68 & 0.31 & 0.38 & 0.11 & 2 & 52 \\
\hline 13 & 18.5 & 2 & 0.78 & 0.26 & 0.21 & 0.14 & 2 & 20 \\
\hline 14 & 14 & 2.5 & 0.74 & 0.46 & 0.32 & 0.18 & 3 & 24 \\
\hline 15 & 17.375 & 2.125 & 0.6125 & 0.2975 & 0.265 & 0.12 & 2.5 & 39 \\
\hline & - & - & - & - & - & - & - & - \\
\hline & - & - & - & - & - & - & - & - \\
\hline 16 & 13.5 & 2.5 & 0.74 & 0.35 & 0.43 & 0.16 & 4 & 40 \\
\hline 17 & 13.5 & 3 & 0.72 & 0.36 & 0.39 & 0.15 & 3 & 60 \\
\hline 18 & 17 & 3 & 0.81 & 0.62 & 0.41 & 0.25 & 3 & 60 \\
\hline 19 & 25 & 3 & 0.95 & 0.57 & 0.49 & 0.26 & 4 & 52 \\
\hline 20 & 17.25 & 2.875 & 0.805 & 0.475 & 0.43 & 0.205 & 3.5 & 53 \\
\hline- & & & & & & & & \\
\hline 21 & 22 & 3 & 0.36 & 0.54 & 0.21 & 0.19 & 3 & 48 \\
\hline 22 & 20.5 & 2.5 & 0.15 & 0.39 & 0.09 & 0.11 & 3 & 56 \\
\hline 23 & 17.5 & 3 & 0.31 & 0.35 & 0.11 & 0.14 & 3 & 48 \\
\hline 24 & 11 & 0.5 & 0.01 & 0.02 & 0.001 & 0.001 & 1 & 40 \\
\hline 25 & 17.75 & 2.25 & 0.2075 & 0.325 & 0.10275 & 0.11025 & 2.5 & 48 \\
\hline & & & & & & & & 64 \\
\hline 26 & 15.5 & 2 & 0.47 & 0.34 & 0.25 & 0.23 & 2 & 60 \\
\hline 27 & 20 & 2.5 & 0.39 & 0.27 & 0.16 & 0.11 & 3 & 60 \\
\hline 28 & 17 & 3 & 0.31 & 0.21 & 0.06 & 0.05 & 3 & \\
\hline 29 & 15 & 4 & 0.03 & 0.23 & 0.01 & 0.12 & 3 & \\
\hline 30 & 16.875 & 2.875 & 0.3 & 0.2625 & 0.12 & 0.1275 & 2.75 & \\
\hline & & & & & & & & \\
\hline
\end{tabular}


Appendix 3. Cumulative data of pot replication in different treatment

\begin{tabular}{|c|c|c|c|c|c|c|c|c|c|c|c|}
\hline $\begin{array}{c}\text { Pot } \\
\text { number }\end{array}$ & 8 & 12 & 16 & 20 & 24 & 28 & 32 & 36 & 40 & sum & gmt \\
\hline 1 & 0 & 2 & 3 & 2 & 1 & 1 & 1 & 0 & 0 & 10 & \\
\hline 1 & 0 & 24 & 48 & 40 & 24 & 28 & 32 & 0 & 0 & 196 & 19.6 \\
\hline 2 & 0 & 3 & 2 & 2 & 1 & 1 & 1 & 1 & 0 & 11 & \\
\hline 2 & 0 & 36 & 32 & 40 & 24 & 28 & 32 & 36 & 0 & 228 & 20.72727 \\
\hline 3 & 1 & 1 & 0 & 1 & 2 & 2 & 2 & 1 & 0 & 10 & \\
\hline 3 & 8 & 12 & 0 & 20 & 48 & 56 & 64 & 36 & 0 & 244 & 24.4 \\
\hline 4 & 0 & 2 & 2 & 0 & 1 & 1 & 1 & 0 & 0 & 7 & \\
\hline 4 & 0 & 24 & 32 & 0 & 24 & 28 & 32 & 0 & 0 & 140 & 20 \\
\hline 5 & 1 & 1 & 1 & 2 & 1 & 2 & 1 & 0 & 0 & 9 & \\
\hline 5 & 8 & 12 & 16 & 40 & 24 & 56 & 32 & 0 & 0 & 188 & 20.88889 \\
\hline 6 & 0 & 1 & 1 & 1 & 0 & 1 & 1 & 2 & 2 & 9 & \\
\hline 6 & 0 & 12 & 16 & 20 & 0 & 28 & 32 & 72 & 80 & 260 & 28.88889 \\
\hline 7 & 0 & 1 & 3 & 1 & 2 & 1 & 2 & 1 & 0 & 11 & \\
\hline 7 & 0 & 12 & 48 & 20 & 48 & 28 & 64 & 36 & 0 & 256 & 23.27273 \\
\hline 8 & 0 & 1 & 1 & 1 & 2 & 3 & 1 & 1 & 1 & 11 & \\
\hline 8 & 0 & 12 & 16 & 20 & 48 & 84 & 32 & 36 & 40 & 288 & 26.18182 \\
\hline 9 & 0 & 1 & 1 & 2 & 0 & 1 & 1 & 1 & 1 & 8 & \\
\hline 9 & 0 & 12 & 16 & 40 & 0 & 28 & 32 & 36 & 40 & 204 & 25.5 \\
\hline 10 & 0 & 1 & 1 & 0 & 1 & 1 & 2 & 3 & 0 & 9 & \\
\hline 10 & 0 & 12 & 16 & 0 & 24 & 28 & 64 & 108 & 0 & 252 & 28 \\
\hline 11 & 0 & 1 & 1 & 2 & 1 & 1 & 2 & 0 & 0 & 8 & \\
\hline 11 & 0 & 12 & 16 & 40 & 24 & 28 & 64 & 0 & 0 & 184 & 23 \\
\hline 12 & 0 & 1 & 1 & 0 & 2 & 2 & 3 & 1 & 1 & 11 & \\
\hline 12 & 0 & 12 & 16 & 0 & 48 & 56 & 96 & 36 & 40 & 304 & 27.63636 \\
\hline 13 & 0 & 1 & 1 & 1 & 1 & 2 & 3 & 4 & 0 & 13 & \\
\hline 13 & 0 & 12 & 16 & 20 & 24 & 56 & 96 & 144 & 0 & 368 & 28.30769 \\
\hline 14 & 0 & 1 & 1 & 1 & 1 & 2 & 3 & 1 & 0 & 10 & \\
\hline 14 & 0 & 12 & 16 & 20 & 24 & 56 & 96 & 36 & 0 & 260 & 26 \\
\hline 15 & 0 & 0 & 1 & 1 & 1 & 2 & 2 & 1 & 0 & 8 & \\
\hline 15 & 0 & 0 & 16 & 20 & 24 & 56 & 64 & 36 & 0 & 216 & 27 \\
\hline 16 & 0 & 1 & 1 & 2 & 2 & 1 & 1 & 0 & 0 & 8 & \\
\hline 16 & 0 & 12 & 16 & 40 & 48 & 28 & 32 & 0 & 0 & 176 & 22 \\
\hline 17 & 0 & 0 & 1 & 1 & 1 & 1 & 2 & 0 & 0 & 6 & \\
\hline 17 & 0 & 0 & 16 & 20 & 24 & 28 & 64 & 0 & 0 & 152 & 25.33333 \\
\hline 18 & 0 & 2 & 1 & 0 & 0 & 1 & 1 & 0 & 0 & 5 & \\
\hline 18 & 0 & 24 & 16 & 0 & 0 & 28 & 32 & 0 & 0 & 100 & 20 \\
\hline 19 & 0 & 1 & 1 & 0 & 0 & 1 & 2 & 0 & 0 & 5 & \\
\hline 19 & 0 & 12 & 16 & 0 & 0 & 28 & 64 & 0 & 0 & 120 & 24 \\
\hline 20 & 0 & 1 & 0 & 0 & 0 & 0 & 1 & 1 & 0 & 3 & \\
\hline 20 & 0 & 12 & 0 & 0 & 0 & 0 & 32 & 36 & 0 & 80 & 26.66667 \\
\hline 21 & 0 & 1 & 2 & 1 & 1 & 3 & 2 & 1 & 1 & 12 & \\
\hline 21 & 0 & 12 & 32 & 20 & 24 & 84 & 64 & 36 & 40 & 312 & 26 \\
\hline 22 & 0 & 1 & 1 & 0 & 0 & 0 & 0 & 0 & 0 & 2 & \\
\hline 22 & 0 & 12 & 16 & 0 & 0 & 0 & 0 & 0 & 0 & 28 & 14 \\
\hline 23 & 0 & 2 & 1 & 1 & 0 & 2 & 1 & 1 & 0 & 8 & \\
\hline 23 & 0 & 24 & 16 & 20 & 0 & 56 & 32 & 36 & 0 & 184 & 23 \\
\hline 24 & 0 & 1 & 1 & 1 & 1 & 2 & 1 & 0 & 0 & 7 & \\
\hline 24 & 0 & 12 & 16 & 20 & 24 & 56 & 32 & 0 & 0 & 160 & 22.85714 \\
\hline 25 & 0 & 2 & 4 & 3 & 0 & 3 & 2 & 2 & 1 & 17 & \\
\hline 25 & 0 & 24 & 64 & 60 & 0 & 84 & 64 & 72 & 40 & 408 & 24 \\
\hline 26 & 1 & 1 & 1 & 3 & 3 & 4 & 1 & 0 & 0 & 14 & \\
\hline 26 & 8 & 12 & 16 & 60 & 72 & 112 & 32 & 0 & 0 & 312 & 22.28571 \\
\hline
\end{tabular}




\begin{tabular}{|c|c|c|c|c|c|c|c|c|c|c|c|}
\hline 27 & 0 & 1 & 1 & 1 & 0 & 2 & 0 & 0 & 0 & 5 & \\
\hline 27 & 0 & 12 & 16 & 20 & 0 & 56 & 0 & 0 & 0 & 104 & 20.8 \\
\hline 28 & 0 & 1 & 1 & 1 & 2 & 1 & 1 & 0 & 0 & 7 & \\
\hline 28 & 0 & 12 & 16 & 20 & 48 & 28 & 32 & 0 & 0 & 156 & 22.28571 \\
\hline 29 & 1 & 1 & 1 & 2 & 3 & 1 & 1 & 1 & 0 & 11 & \\
\hline 29 & 8 & 12 & 16 & 40 & 72 & 28 & 32 & 36 & 0 & 244 & 22.18182 \\
\hline 30 & 1 & 2 & 1 & 2 & 1 & 3 & 2 & 1 & 2 & 15 & \\
\hline 30 & 8 & 24 & 16 & 40 & 24 & 84 & 64 & 36 & 80 & 376 & 25.06667 \\
\hline 31 & 1 & 1 & 4 & 3 & 2 & 1 & 2 & 1 & 1 & 16 & \\
\hline 31 & 8 & 12 & 64 & 60 & 48 & 28 & 64 & 36 & 40 & 360 & 22.5 \\
\hline 32 & 3 & 3 & 2 & 2 & 1 & 0 & 1 & 1 & 0 & 13 & \\
\hline 32 & 24 & 36 & 32 & 40 & 24 & 0 & 32 & 36 & 0 & 224 & 17.23077 \\
\hline 33 & 3 & 2 & 1 & 1 & 1 & 0 & 0 & 0 & 0 & 8 & \\
\hline 33 & 24 & 24 & 16 & 20 & 24 & 0 & 0 & 0 & 0 & 108 & 13.5 \\
\hline 34 & 3 & 2 & 2 & 1 & 2 & 2 & 2 & 1 & 0 & 15 & \\
\hline 34 & 24 & 24 & 32 & 20 & 48 & 56 & 64 & 36 & 0 & 304 & 20.26667 \\
\hline 35 & 1 & 1 & 1 & 2 & 2 & 2 & 3 & 1 & 0 & 13 & \\
\hline 35 & 8 & 12 & 16 & 40 & 48 & 56 & 96 & 36 & 0 & 312 & 24 \\
\hline 36 & 1 & 2 & 1 & 1 & 2 & 1 & 2 & 1 & 0 & 11 & \\
\hline 36 & 8 & 24 & 16 & 20 & 48 & 28 & 64 & 36 & 0 & 244 & 22.18182 \\
\hline 37 & 2 & 3 & 2 & 2 & 2 & 1 & 2 & 2 & 1 & 17 & \\
\hline 37 & 16 & 36 & 32 & 40 & 48 & 28 & 64 & 72 & 40 & 376 & 22.11765 \\
\hline 38 & 0 & 2 & 3 & 2 & 1 & 3 & 2 & 1 & 1 & 15 & \\
\hline 38 & 0 & 24 & 48 & 40 & 24 & 84 & 64 & 36 & 40 & 360 & 24 \\
\hline 39 & 2 & 2 & 2 & 2 & 1 & 1 & 2 & 1 & 0 & 13 & \\
\hline 39 & 16 & 24 & 32 & 40 & 24 & 28 & 64 & 36 & 0 & 264 & 20.30769 \\
\hline 40 & 2 & 3 & 2 & 3 & 2 & 2 & 1 & 1 & 0 & 16 & \\
\hline 40 & 16 & 36 & 32 & 60 & 48 & 56 & 32 & 36 & 0 & 316 & 19.75 \\
\hline 41 & 0 & 0 & 0 & 0 & 0 & 0 & 0 & 0 & 0 & & \\
\hline 42 & 0 & 0 & 0 & 0 & 0 & 0 & 0 & 0 & 0 & & \\
\hline 43 & 0 & 0 & 0 & 0 & 0 & 0 & 0 & 0 & 0 & & \\
\hline 44 & 0 & 0 & 0 & 0 & 0 & 0 & 0 & 0 & 0 & & \\
\hline
\end{tabular}

